\title{
Reemployment of Displaced Workers - The Case of a Plant Closing on a Remote Region in Finland
}

I Arja Jolkkonen

Senior Researcher, Karelian Institute, University of Eastern Finland, Finland

I Pertti Koistinen

Professor, School of Social Sciences and Humanities, University of Tampere, Finland ${ }^{1}$

I Arja Kurvinen

Senior Researcher, Karelian Institute, University of Eastern Finland, Finland

\begin{abstract}
The aims of this article are to examine the reemployment of displaced workers and individual factors that predict reemployment and education, earnings in new jobs, and paths to reemployment. This article is based on a case study' of the closing down of the Perlos Ltd plants in North Karelia in eastern Finland. From the 1990s, the Perlos Corporation grew from a Nokia subcontractor into a globally operating limited company with a global workforce of over 13,000 workers and almost 2,000 workers in North Karelia. In 2007, the corporation closed down all its production activities in Finland. In the case study, various data sources were used but this article is based mainly on the questionnaire conducted in 2008 among 1,217 trade union members. Logistic and multinomial regression analyses are used as analysis methods. Against expectations, the fast reemployment of the displaced workers was a surprise, which can be explained by the good demand and hidden need for labor in other firms in this region. However, the demand was specific and differentiated between the workers' job opportunities. White-collar workers had better chances of reemployment. Gender, next to the occupational status, was an important predictor for reemployment. On the other hand, education, the willingness to move, and family status were not statistically significant explanatory factors for reemployment. The age of the job seekers was one important factor predicting unemployment.
\end{abstract}

\section{KEY WORDS}

Plant closing / displaced workers / reemployment / unemployment / loss of earnings / job search.

\section{Introduction}

ob loss creates a social risk for individuals. The risks consist of unemployment, difficulties in reemployment, and reduction in income, but job loss can also have negative effects on health, well-being, and family life. However, one important fact is that job displacements and their social consequences are selective, in which societal, individual, and local factors influence the outcomes (Bittaraev 2011; Erikson 2002;

\footnotetext{
${ }^{1}$ Pertti Koistinen, Professor, School of Social Sciences and Humanities, FI-33014, University of Tampere, Finland, E-mail: pertti.koistinen@uta.fi
} 
Frederiksen and Westergaard-Nielsen 2007; Jolkkonen 1998; Jolkkonen and Kurvinen 2009; Kurvinen 1999, 2001; Melin and Mamia 2010).

Based on existing research, we know that in the long run, the reemployment of displaced workers and their future earnings strongly depend on the economic cycle and labor demand. The reemployment of displaced workers is also affected by professional skills, work history, education, age and gender, preferences and resources, and the competitive positions of different groups searching for jobs (Houle and von Audenrode 1995; Jolkkonen and Koistinen 2002; Kletzer 1998; Korkeamäki and Kyyrä 2008).

The Perlos plants closed down in 2007 when there was still an increased demand for labor, but the small size of the local labor market and the location of the Perlos plants far from the large centers weakened reemployment opportunities. There was no demand for the special skills and qualifications of the displaced workers, which led to the hypothesis that reemployment in one's previous occupation, would be difficult. Therefore, it was expected that the individual's resources and labor market behavior, such as labor market participation, search for educational options, job search, occupational and regional mobility, and wage expectations directly and indirectly affect reemployment.

The Perlos case is also interesting for several other reasons. The extensive support measures targeted toward the laid-off workers were more extensive than ever before in Finland. Among the measures, there was the Finnish flexicurity model, the change security model $^{2}$ implemented in 2005, and the additional resources obtained through the European Globalisation Adjustment Fund (EGF). The extensive job loss at Perlos mobilized national and local actors to offer support to the region undergoing structural change and to the displaced workers. Along with the labor authorities, the organizers of the support measures included educational organizations, trade unions, the local entrepreneurs association, the Evangelical Lutheran Church, and the local regional development company. The support actions that followed the closing of the plant provided a true test for the Finnish change security model and also for the EGF, because Finland was among the first countries to receive funding from the EGF (Jolkkonen and Kurvinen 2009).

The reemployment opportunities of the displaced workers were expected to be positive, not only because of the existing support mechanisms but also because the average age of the employees in the company was only 34 years and their educational background was heterogeneous. In the late 1990s and at the beginning of the 2000s, the company recruited from its immediate surroundings a lot of new labor, who already had a vocational education and whom the company retrained according to its own needs (Jolkkonen and Kurvinen 2009; Kangasharju and Pekkala 2001; Kauhanen et al. 2006; Melin and Mamia 2010; Myrskylä 2006; Pekkala and Kangasharju 2002). On the basis of earlier studies, we assume that reintegration into the labor market is strongly selective.

\section{Reemployment and the development of earnings - Theoretical premises}

The tradition of research on plant closures and their effects on the labor market is unique in Finland; due to the lack of representative data, nearly all the Finnish studies have been case studies (Jolkkonen and Kurvinen 2009; Koistinen and Suikkanen 1990). 
However, the situation has improved in recent years since Statistics Finland began to produce the Finnish Linked Employer-Employee Data, which allow for longitudinal analysis. In the Netherlands, France, and Denmark, there has been a longer tradition of using linked employer-employee data to study labor market transitions. In the United States, the Displaced Worker Survey has been conducted since 1984 (Carrington 1993; Frederiksen and Westergaard-Nielsen 2007; Kletzer 1998). Previous studies clearly indicate that job loss has short-term and long-term consequences for the individuals' later careers, earnings, and welfare development (Eliason 2004; Gallo et al. 2001; Lucas et al. 2004; Martikainen et al. 2007; Sullivan and von Wachter 2006).

The case studies conducted in Finland indicate that in addition to the economic cycles, the reemployment of displaced workers depends on the structure and functioning of the local labor market, factors related to the job seekers, and the competition between the various groups of job seekers. The most important individual factors are professional skills, occupational status, education, previous work history, age, and gender. In labor reductions, the first to lose jobs are the temporary workers, whose contracts will not be renewed, and the oldest employees, who are encouraged to make early retirement plans. Some workers will resign voluntarily if they find another job fast. If the company continues production or sells their production to another company, reemployment opportunities can also open up to the former workers. For a remarkable share of the displaced workers, especially for the elderly ones, there is a risk of becoming long-term unemployed or of moving out of the labor force. Others enter training or retraining in order to find a job in their former occupation or to change occupations. Migration and commuting may offer reemployment or career development opportunities and be alternatives to occupational mobility. Even self-employment and entrepreneurship can be seen as an option for some (Jolkkonen 1998; Jolkkonen and Kurvinen 2009; Koistinen 2002; Koistinen and Suikkanen 1990; Kurvinen 1999; Linnakangas 1997; Melin and Mamia 2010; Rouvinen 2003).

Job loss has short-term and long-term consequences for the workers' future income and reemployment. This reduction in income has been explained by the theories of human capital, as well as wage formation. According to the human capital theory, the firm-specific skills and human capital are risky because they cannot be transferred. When one loses a job, one may also lose human capital because his or her qualifications do not have a trade-in value for other employers. This leads to the fact that the displaced worker's resources to compete for jobs weaken and he or she will have difficulties in maintaining the earlier professional status. Several layoffs and periods of unemployment produce a shortage of human capital, in addition to which unemployment can also weaken one's general skills and well-being. Repeated periods of unemployment seem to have a cumulative impact on a person's productivity; thus, they reduce the later earnings levels (Kletzer 1998; Malo and Muñoz-Bullón 2007; Stevens 1997).

In the United States, research based on the Displaced Workers Survey has shown that less educated workers are more likely to be displaced than more educated workers. Production workers lost their jobs more often than other workers, but in the 1990s job losses also became more frequent among other employment groups. The reemployment probabilities are noticeably cyclical: during the years 1981 to 1995 , the employment probabilities of displaced workers rose with the economic boom and fell during recession. Those with higher education are more likely to be reemployed than those with a lower educational level. Furthermore, reemployment seemed affected by gender since 
women's chances of reemployment became lower than those of men. One-third of the workers had lower predisplacement earnings, while 30-40\% of the displaced workers earned more on their postdisplacement. The change in the earnings level depended on how the workers managed to find new full-time employment (Kletzer 1998). According to William Carrington (1993), there are also occupational, industrial, and regional differences in reemployment and earnings development. The conditions of the local labor market in which the workers are displaced play an important role in postdisplacement employment and wage outcomes. The workers displaced from slumping industries experienced significantly greater wage losses than workers displaced from growing industries. Highly experienced workers have larger displacement-induced wage losses and their unemployment spells are longer than others. One explanation for this may be that the skills developed in permanent employment are specific to the firm. On the other hand, the influence of the local labor market and economic situation on the earnings development of displaced workers varies according to the occupation and industry. The occupation and industry may define which skills are transferable and how other employers reward them. Research on layoffs has shown that the workers who moved to another industry experience greater income reduction than those who become reemployed in their former field. This may be due to the industrial agreements and variations in the wage levels but also to the fact that those remaining in the same field benefit from the human capital they have accumulated, whereas those changing fields do not (Carrington 1993; Kletzer 1998).

Several longitudinal studies have also shown persistence in wage reductions that follow displacement. One reason for these persistent losses is the multiple displacements occurring for a given worker. Significant earnings reductions begin in the year prior to the displacement. In the year of displacement, annual earnings are reduced but the year after the job loss, earnings recover as workers are reemployed (Stevens 1997). One factor significantly related to reemployment and earnings is whether the person is being laid-off or has resigned of his/her own will. According to Lea Waters (2007), those who voluntarily resigned experience lower levels of depression and engaged in more job search activity than those who experienced involuntary job loss.

In the Nordic countries, where the process of displacement is based on collective agreements and the income losses compensated for by the social security systems of the welfare state, the income effects of job loss are expected to be lower and to spread more equally among the groups at risk. When evaluating these results in the context of the Nordic countries, we expected that the redistribution effect on the incomes would be noticeable and that the income effect of a job loss may not be as strong as in other socioeconomic systems, such as in the Anglo-American or Continental European countries. However, follow-up studies tell another story. In Finland, the effects of job loss and earnings development have been studied via the use of a wide register-based database. Jukka Appelqvist (2007) found that displaced workers suffer substantial and persistent losses in both their monthly wages and annual earnings: after 5 years from redundancy, their monthly wages are approximately $8-9.5 \%$ lower than of those who had kept their jobs. The workers who were displaced during the recession in 1992 suffered considerably larger losses than those who were displaced in the recovery period in 1997. Ossi Korkeamäki and Tomi Kyyrä (2008) discovered that displaced workers suffer from substantial and persistent losses of earning, women are subject to larger losses, and that the effect of displacement is very heterogeneous, being much larger in the lower 
quintiles. Displacement does not only cause a large loss in the expected earnings but also raises uncertainty about the level of future earnings. Their results confirm that the losses in earnings are related to economic cycles. Seven years after job loss, the medium earnings of those who were displaced during the recession (in 1992) were reduced by approximately $15 \%$ for men and $20 \%$ for women. During the recovery period, job loss had a long-lasting effect only in the lower half of the earnings distribution. Jouko Verho (2008) compared the earnings of the men who lost their jobs during the recession of the early 1990s with the earnings of those who remained in employment. In the analysis, prime working-age men who faced unemployment due to a plant closure were matched against those who remained employed during the recession. The average effect of being unemployed during the recession was estimated for a 6-year follow-up period. After 6 years, there was a $25 \%$ annual earnings penalty for being unemployed. The total number on months in employment recovered steadily after the recession but was still $10 \%$ lower after the 6 -year follow-up. The estimated wage loss was $14 \%$ and it was caused by the reduction of employment months and a lower wage level in the new job.

We suppose that reemployment is selective in terms of age, education, gender, and resources. In addition, the location and structures of the local labor market and labor demand differentiate the job opportunities. Also, we assume that although the displaced workers regain employment, the new earnings will, for many, be lower than they had been before. How fast their earnings reach the level of the other employees or that of the previous job depend on whether the person finds a job which matches his/her skills, and how fast and permanently this reemployment takes place. Assumedly, previous work experience, the labor market position, and the social networks of the job seeker as well as the economic cycle have a significant impact on reemployment and earnings.

\section{Data and methods}

The survey was conducted in 2008 with those employees at Perlos who were members of the Chemical Workers Union (811), Union of Salaried Employees (336), or Union for Professional Engineers (69) in 2006 and 2007. The survey was sent to a total of 1,217 workers via mail and e-mail. A total of 519 responses were received, of which 508 were acceptable. The response rate was $42.6 \%$, which can be considered good. The survey contained 70 questions regarding one's background, work at Perlos, the layoff, the person's behavior and job search, search for education/training, reemployment, regional mobility, satisfaction with work and changes in earnings, livelihood, experiences with the support structures, and the change security.

The survey was also intended for those who resigned voluntarily, were reemployed by the employers who bought some parts of the production operations of Perlos, and those who had temporary work contracts, groups on which no data were available via registry data or documents. This goal was reached, as 355 of the respondents were laid off and 63 had resigned themselves. Most of the respondents $(88 \%)$ had not moved out of the province after losing their jobs. According to occupational status, $64 \%$ of the respondents were blue-collar workers, $29 \%$ were lower white-collar workers, and 7\% were upper whitecollar workers. Half of the respondents were women and the average age was 39.8 years. Compared with the employee structure of Perlos in 2007, women were overrepresented in the survey and the respondents' average age was a little bit higher. 
To analyze the survey data, we created distributions, cross-tabulations, and significance tests. In addition, we used multivariate methods such as logistic and multinomial regression. Logistic and multinomial regression analyses were used to investigate factors that predict reemployment, training, unemployment, and earnings development. In logistic regression, the dependent variable is always binary, for example, "employed" and "not employed". When using the forced method in logistic regression, all potential explanatory factors are included in the model at once. In the stepwise method, the program selects those variables that improve the model fit according to set criteria and leaves out variables with no explanatory power. With multinomial regression analysis, the dependent factor can have several categories. With multinomial regression, within a single model, we can test for the factors that predict the current status: reemployed, in training/education or unemployed. We report the odds ratio (OR) and the variances within a $95 \%$ confidence interval. The ORs are compared with a reference category that has the value of 1 . The OR expresses how likely the event will occur compared with how likely will the event not occur. If the OR is less than 1, then the risks (odds) of the event taking place are smaller than that of the reference category, and vice versa. When ORs are between zero and one (when logistic regression coefficients are negative), we report the inverse odds ratio, IOR. The analyses were done with the SPSS statistics program for forced and stepwise regression analysis, as well as for multinomial regression analysis (using a 0.05 significance level). The asterisks after the ORs are used to indicate statistical significance in the following way: $* p<0.05 ; * *<<0.01 ; * * p<0.001$ (DesJardins 2001; Goldin 2007; Jokivuori and Hietala 2007).

\section{Results}

\section{Integration into the labor market}

When the collective negotiations started at the Perlos plants in the Joensuu region in 2007, there were 1,243 workers, of whom 975 were laid off in September 2007. A year after the closing of production, 921 of the laid-off workers had engaged with the employment office services (Table 1). A total of 54 laid-off workers did not use the services of the employment office and had most likely found employment on their own. Some of the workers had resigned voluntarily and some found employment in companies that continued the operations of Perlos. Those 200 workers who continued to work for Perlos after the first collective negotiations were later a part of the 2008 negotiations, when the owner announced the relocation of the headquarters and the remaining operations to outside of Finland.

After 1 year, $57 \%$ of those who had registered at the employment office were reemployed and most of them had found work on their own (69\% of the reemployed), $18 \%$ were unemployed, and $22 \%$ were in education or training. The number of reemployed grew during the follow-up period, and 5 months after the plant closed the share of those in training was at its highest but went down afterward. Reemployment was faster than expected, which was likely due to economic growth and active labor market measures. Nevertheless, based on the 2007-2008 follow-up data, most of those laid-off workers had at some point in time been unemployed (Jolkkonen and Kurvinen 2009). The number and share of the unemployed begun to increase in the autumn of 2008 when 
Table I The labor market position of the laid-off workers from the Perlos factories of the Joensuu region 3, 5, 7, and II months after the plant closed (September 30, 2007).

\begin{tabular}{lccccccccc}
\hline \multirow{2}{*}{ Labor market position } & \multicolumn{6}{c}{ The period of follow-up after plant closing } \\
\cline { 2 - 11 } & 3 months & 5 months & 7 & months & \multicolumn{1}{c}{ II months } \\
\hline Situation unknown, not registered as job seeker & 80 & 8.3 & 58 & 6.0 & 48 & 5.0 & 54 & 5.5 \\
\hline Registered at the employment office & 885 & 91.7 & 907 & 94.0 & 917 & 95.0 & 921 & 94.5 \\
\hline Total number of laid-off workers & 965 & 100 & 965 & 100 & 965 & 100 & 975 & 100 \\
\hline Of registered job seekers & & & & & & & & \\
Reemployed & 386 & 43.6 & 425 & 46.9 & 474 & 51.7 & 524 & 57.0 \\
$\quad$ by themselves & 270 & 30.5 & 290 & 32.0 & 299 & 32.6 & 362 & 39.3 \\
$\quad$ by the active labor market measures & 116 & 13.1 & 135 & 14.9 & 175 & 19.1 & 162 & 30.9 \\
\hline Still working at Perlos & 11 & 1.2 & 11 & 1.2 & 5 & 0.5 & & \\
\hline In vocational training/education & 244 & 27.6 & 275 & 30.3 & 275 & 30.0 & 203 & 22.0 \\
\hline On sick/maternity leave or pension & 25 & 2.8 & 39 & 4.3 & 39 & 4.3 & 28 & 3.0 \\
\hline Unemployed & 219 & 24.7 & 157 & 17.3 & 124 & 13.5 & 166 & 18.0 \\
\hline Total number of registered job seekers & 885 & 100 & 907 & 100 & 917 & 100 & 921 & 100 \\
\hline N & & & & & & & & \\
\hline
\end{tabular}

$\mathrm{N}$ represents the number of laid-off workers.

(Source: Employment Office of Joensuu region)

the possibilities for reemployment started to reduce due to an economic slowdown. One year after the plant closed $24 \%$, and after 2.5 years almost one-third, of the laid-off workers were unemployed.

The rapid reemployment right after the plant closed can be explained not only by the strong demand for labor but also by the lemon effect of layoffs, as described by Gibbons and Katz (1991). According to them, those losing their jobs in plant closures are considered more desirable labor than those laid-off due to workforce reductions because their work ability and productivity are supposed to be low. They also found that unemployment spells are longer and wage losses larger for those displaced by reductions than those displaced by plant closure. The lemon effect is understandable and easily accepted in the theoretical and political argumentation but we have to be careful with the interpretation of the research results, since the differences in reemployment and the decline in earnings levels can be explained by other reasons as well (Song 2007).

\section{Factors that predict reemployment}

Table 1 describes the labor market status of those laid-off people who had registered as job seekers or unemployed but it does not describe the labor market position of those who had never used the services of the employment office. The survey data also cover those displaced workers who resigned voluntarily and found a new job without registering at the employment office. 
According to the survey, 10 months after the plant closed, $61 \%$ of the respondents were employed, $19 \%$ were in education or training, $14 \%$ were unemployed, $1 \%$ were entrepreneurs and 5\% were outside the labor market. Of the employed, $16 \%$ had short-term work contacts; $28 \%$ of the women and only $9 \%$ of the men were employed temporarily, which showed that the women were more flexible than the men in accepting short-term contracts. Among women, the average length of the short-term contracts was half a year and among men 10 months. Of the reemployed, 93\% worked full-time, so flexible working hours in terms of accepting part-time work as a stepping stone to employment was rarely used. Of the reemployed, $70 \%$ continued in the same field of industry and the others were fairly evenly divided into the different branches. Two-thirds were employed in large or medium-sized companies and one-fourth in small ones. Only $6 \%$ of the employed changed to the public sector, which was surprising because many of the displaced women had multiple qualifications and adequate work experience for public sector jobs. The upper white-collar workers managed to retain upper white-collar positions also in their new jobs and only a few blue-collar workers moved to the lower white-collar position. Instead, of the lower white-collar workers, only $63 \%$ stayed in the same position, $19 \%$ moved to the upper white-collar workers, and $16 \%$ to blue-collar workers. Only a few became entrepreneurs.

Based on previous research results, we expected the following social selectivity during reintegration (Jolkkonen 1998; Jolkkonen and Kurvinen 2009; Koistinen and Suikkanen 1990; Kurvinen 1999; Linnakangas 1997; Melin and Mamia 2010; Rouvinen 2003):

- Age affects reemployment, so that young workers have better chances of reemployment than older workers; $40+$ ages have a negative effect on reemployment.

- The better educated have better chances of reemployment than those less educated.

- A long career in a single firm has a negative impact on reemployment.

- Narrow expertise prohibits reemployment.

- White-collar workers have better reemployment opportunities than blue-collar workers.

- Regional mobility increases reemployment opportunities.

- Private ownership of housing and a family reduce the willingness to migrate and as such they have a negative impact on reemployment.

Using the forced model of logistic regression, the probability of reemployment was predicted. Gender, age, migration, occupational status and the duration of the work contract in the company, the ownership of a dwelling, family status, and education were used as predictors (Table 2).

The model explained $26 \%$ of the variance (Nagelkerke $R$ Square 0.260 ) and fit very well with the data (Hosmer and Lemeshow test 0.141 /as such $>0.05$ ). The model is highly useful for predicting reemployment; it gave the correct estimate for $78.7 \%$ of the cases in the category of the employed. In general, the estimation ratio of the model was $69.3 \%$.

The most significant predictive variables for reemployment were "gender" and "former occupational status". Men were much more likely to be reemployed than women and the white-collar workers' possibilities to be reemployed were substantially higher than that of the blue-collar workers. In addition, age and the duration of the work contract also had predictive value. Those aged 50 or more were less likely to be reemployed than 
Table 2 Factors predicting the reemployment of displaced workers.

\begin{tabular}{|c|c|c|c|}
\hline Predictors of reemployment & $\operatorname{Exp}(B)+$ sig./OR & IOR & Confidence interval 95\% \\
\hline $\begin{array}{l}\text { Gender } \\
\text { Women } \\
\text { Men } \\
\end{array}$ & $\begin{array}{l}\text { I } \\
2.98 * * * * 1\end{array}$ & & $(1.96-4.54)$ \\
\hline $\begin{array}{l}\text { Age } \\
\text { under } 35 \text { years } \\
35-49 \text { years } \\
\text { over } 50 \text { years } \\
\end{array}$ & $\begin{array}{l}\text { I** } \\
0.74 \\
0.35 * *\end{array}$ & $\begin{array}{l}1.35 \\
2.86 \\
\end{array}$ & $\begin{array}{l}(0.42-1.30) \\
(0.17-0.71) \\
\end{array}$ \\
\hline $\begin{array}{l}\text { Migration } \\
\text { Out-migration from the province } \\
\text { No migration }\end{array}$ & $\begin{array}{l}1 \\
0.69 \\
\end{array}$ & 1.45 & $(0.29-1.66)$ \\
\hline $\begin{array}{l}\text { Occupational status } \\
\text { Blue-collar workers } \\
\text { White-collar workers } \\
\end{array}$ & $\begin{array}{l}\text { I } \\
2.84 * * * * 1\end{array}$ & & $(1.66-4.84)$ \\
\hline $\begin{array}{l}\text { Duration of the work contract } \\
\qquad \begin{array}{l}1-3 \text { years } \\
4-9 \text { years } \\
10 \text { years or more }\end{array}\end{array}$ & $\begin{array}{l}\text { I* } \\
2.38 * * \\
1.92 \\
\end{array}$ & & $\begin{array}{l}(1.31-4.30) \\
(0.98-3.76) \\
\end{array}$ \\
\hline $\begin{array}{l}\text { Owner-occupied flat } \\
\text { No } \\
\text { Yes }\end{array}$ & $\begin{array}{l}1 \\
1.56 \\
\end{array}$ & & $(0.92-2.62)$ \\
\hline $\begin{array}{l}\text { Children in the family } \\
\text { No children under } 16 \text { years } \\
\text { Have children under } 16 \text { years }\end{array}$ & $\begin{array}{l}1 \\
0.79 \\
\end{array}$ & 1.27 & $(0.50-1.25)$ \\
\hline $\begin{array}{l}\text { Education } \\
\text { No vocational education } \\
\text { Secondary level } \\
\text { Tertiary level }\end{array}$ & $\begin{array}{l}1 \\
1.19 \\
1.66\end{array}$ & & $\begin{array}{l}(0.65-2.19) \\
(0.69-3.97)\end{array}$ \\
\hline
\end{tabular}

Forced logistic regression, the risk ratio, and statistical significance; significance levels: $* p<0.05$, $* * p<0.0$ I, $* * * *<<0.00$ ।

those younger than 35 years. Employers seemed to value work experience, as those who had been employed for 4-9 years were more likely to be reemployed than those who had been employed for less than 4 years. Those employed for over 10 years were more likely to be reemployed than those employed for less than 4 years. Based on the results, we argue that work experience could at least partially compensate for the difficulties caused by the job seekers' older age.

Forward stepwise regression analysis was also performed with the data. The stepwise model selected gender as the first significant explanatory factor for reemployment. The second most important factor was occupational status, followed by the duration of the work contract and the age of the job-seeker. Other factors, such as education, were left out as they did not improve the model fit. The occupational status and the duration of the contract were, as such, more important explanatory factors than education. The intensity of the search for work was also tested for being an explanatory variable, but it did not predict the probability of the employment. Thus, the means and intensity of the job search are analyzed separately. 
The models used were at their best when estimating reemployment. When used for predicting unemployment or moving into training or education, the models were at their weakest. When estimating unemployment with logistic regression, "age" was the most significant explanatory factor. When "age" was left out of the model, the other factors did not have statistical significance.

\section{Predictors for educational choices and the risks of unemployment}

The analysis of labor market integration was continued with multinomial regression analysis, in which the reference category was "reemployed". The model investigated the predictive factors for starting education/training and moving into unemployment in comparison with the employed (Table 3).

Table 3 The risks of the displaced workers entering into education and training or unemployment compared with becoming reemployed.

\begin{tabular}{|c|c|c|c|c|}
\hline \multirow[t]{2}{*}{ Predictors } & \multicolumn{2}{|c|}{$\begin{array}{l}\text { In training or education } \\
\text { versus employed }\end{array}$} & \multicolumn{2}{|c|}{$\begin{array}{l}\text { Unemployed versus } \\
\text { employed }\end{array}$} \\
\hline & OR & IOR & OR & IOR \\
\hline $\begin{array}{l}\text { Gender } \\
\text { Women } \\
\text { Men } \\
\end{array}$ & $\begin{array}{l}3.30 * * * * \\
1\end{array}$ & & $\begin{array}{l}1.57 \\
1\end{array}$ & \\
\hline $\begin{array}{l}\text { Age } \\
\text { under } 35 \text { years } \\
35-49 \text { years } \\
\text { over } 50 \text { years }\end{array}$ & $\begin{array}{l}0.60 \\
0.88 \\
1\end{array}$ & $\begin{array}{l}1.67 \\
1.14\end{array}$ & $\begin{array}{l}0.09 * * * * \\
0.31 * * * \\
1\end{array}$ & $\begin{array}{l}11.11 \\
3.23\end{array}$ \\
\hline $\begin{array}{l}\text { Children in the family } \\
\text { No children under } 16 \text { years } \\
\text { Have children under } 16 \text { years }\end{array}$ & $\begin{array}{l}0.87 \\
1\end{array}$ & 1.15 & $\begin{array}{l}1.21 \\
1\end{array}$ & \\
\hline $\begin{array}{l}\text { Migration } \\
\text { Out-migration from the province } \\
\text { No migration }\end{array}$ & $\begin{array}{l}0.21(*) \\
1\end{array}$ & 4.76 & $\begin{array}{l}0.55 \\
1\end{array}$ & 1.82 \\
\hline $\begin{array}{l}\text { Owner-occupied flat } \\
\text { No } \\
\text { Yes }\end{array}$ & $\begin{array}{l}1.61 \\
1 \\
\end{array}$ & & $\begin{array}{l}2.3^{*} \\
1 \\
\end{array}$ & \\
\hline $\begin{array}{l}\text { Education } \\
\text { No vocational education } \\
\text { Secondary level } \\
\text { Tertiary level }\end{array}$ & $\begin{array}{l}2.12 \\
1.69 \\
1\end{array}$ & & $\begin{array}{l}0.72 \\
0.84 \\
1\end{array}$ & $\begin{array}{l}1.39 \\
1.19\end{array}$ \\
\hline $\begin{array}{l}\text { Occupational status } \\
\text { Blue-collar worker } \\
\text { White-collar worker }\end{array}$ & $\begin{array}{l}4.05 * * * * \\
1\end{array}$ & & $\begin{array}{l}2.38 * \\
1\end{array}$ & \\
\hline $\begin{array}{l}\text { Duration of work contract } \\
\text { 1-3 years } \\
4-9 \text { years } \\
10 \text { years or more }\end{array}$ & $\begin{array}{l}2.21 * \\
0.98 \\
1\end{array}$ & 1.02 & $\begin{array}{l}2.47 * \\
0.64 \\
1\end{array}$ & 1.56 \\
\hline
\end{tabular}

Multinomial regression analysis, the risk ratio, and statistical significance; significance levels: $* p<0.05, * * p<0.0$ I, $* * * * 0.00$ I 
According to the analysis, the multinomial model fits the data well and its explanatory level was $28 \%$ (Nagelkerke 0.283 ). Again the model predicted reemployment the best $(90 \%$ of the cases could be correctly predicted) and unemployment and education/ training at least as well. All in all, the model could select $65 \%$ of the cases correctly. It seems that other factors besides those measured by the variables in the survey partly explain education/training and unemployment.

When using "employed" as the reference category, the women were more likely to end up in training/education than men. The blue-collar workers' probability of moving into training/education was much higher compared with that of the white-collar workers. The comparisons also showed that those who stayed in the region were more likely to have started training/education than those who migrate from the province. Those who had worked for less than 4 years in the company were more likely to end up in training/education than those having worked for longer than 10 years. Age or previous education on the other hand did not significantly predict moving into training/education when "employed" was used as the reference category.

When comparing the reemployed with those who remained unemployed, "age" became the most significant explanatory factor. The risk of unemployment for those over 50 years old was much higher in comparison with those who were under 35 years old or with those who were 35-49 years old. For blue-collar workers, the risk of unemployment was higher than that of the white-collar workers. Those with work histories of less than 4 years at Perlos had a higher risk of becoming unemployed in comparison with those who had worked at Perlos for more than 10 years. Also, for those living in other than privately owned housing, the risk of unemployment was higher than that of those owning their own dwelling. On the other hand, migration, education, gender, or having children did not significantly predict unemployment when compared with the employed.

Our results support previous studies (Carrington 1993; Kletzer 1998; Malo and Muñoz-Bullón 2007; Stevens 1997) that state reintegration into the labor market is selective according to age, gender, and occupational status. Gender and occupational status were the most important predictors for reemployment. Age was, as expected, an important factor for predicting the risk of unemployment. Labor market training and adult education seem to function according to their objectives, because they reached those groups whose reemployment after the layoff proved to be the most difficult.

\section{The earnings changes of reemployed workers}

Losing a job is a multi-faceted process that can be experienced as a new opportunity and challenge but at the worst it can bring deepened inequality and earnings losses. The previous studies led to the hypothesis that the earnings level of the displaced workers would decrease both in the shorter and longer term, but that there might be significant variation between the different groups. Also, previous research results support the argument according to which those who are laid off have greater earnings losses than those who resign voluntarily.

The respondents were asked to estimate the change in their total monthly earnings. According to our findings, $38 \%$ of the respondents had had a reduction in their earnings, 
for one-third the earnings had remained the same, and 30\% earned more in the new job than previously at Perlos. Of those who resigned voluntarily before the plant was closed, more than half reported increase in earnings, whereas $40 \%$ of the people laid-off and $60 \%$ of those with temporary work contracts earned less than before. Almost all who were reemployed by the employers who bought some parts of the production operations of Perlos said that their earnings remained the same (Table 4).

Blue-collar workers experienced a decline in earnings more often than white-collar workers. More than half of the blue-collar workers and one quarter of the white-collar workers reported that earnings declined. Almost half of the white-collar workers reported an increase in earnings, whereas only $10 \%$ of the blue-collar workers earned more in their new job (Figure 1).

Table 4 Changes in the earnings level of the reemployed based on the reason for leaving the company.

\begin{tabular}{lcccccccc}
\hline \multirow{2}{*}{ Reason for leaving } & \multicolumn{7}{c}{ Changes in earnings } \\
\cline { 2 - 11 } & \multicolumn{2}{c}{ Decreased } & \multicolumn{2}{c}{ Increased } & \multicolumn{2}{c}{ Stable } & \multicolumn{2}{c}{ Total } \\
\hline & $N$ & $\%$ & $N$ & $\%$ & $N$ & $\%$ & $N$ & $\%$ \\
\hline Laid off & 65 & 41.4 & 38 & 24.2 & 54 & 34.4 & 157 & 100 \\
\hline Resigned voluntarily & 14 & 29.8 & 24 & 51.1 & 9 & 19.1 & 47 & 100 \\
\hline Temporarily employed & 6 & 60.0 & 4 & 40.0 & 0 & 0.0 & 10 & 100 \\
\hline Reemployed by a new employer & 0 & 0.0 & 2 & 20.0 & 8 & 80.0 & 10 & 100 \\
\hline Total & 85 & 37.9 & 68 & 30.4 & 71 & 31.7 & 224 & 100 \\
\hline
\end{tabular}

Figure I: Changes in earnings of the reemployed according to their occupational status.

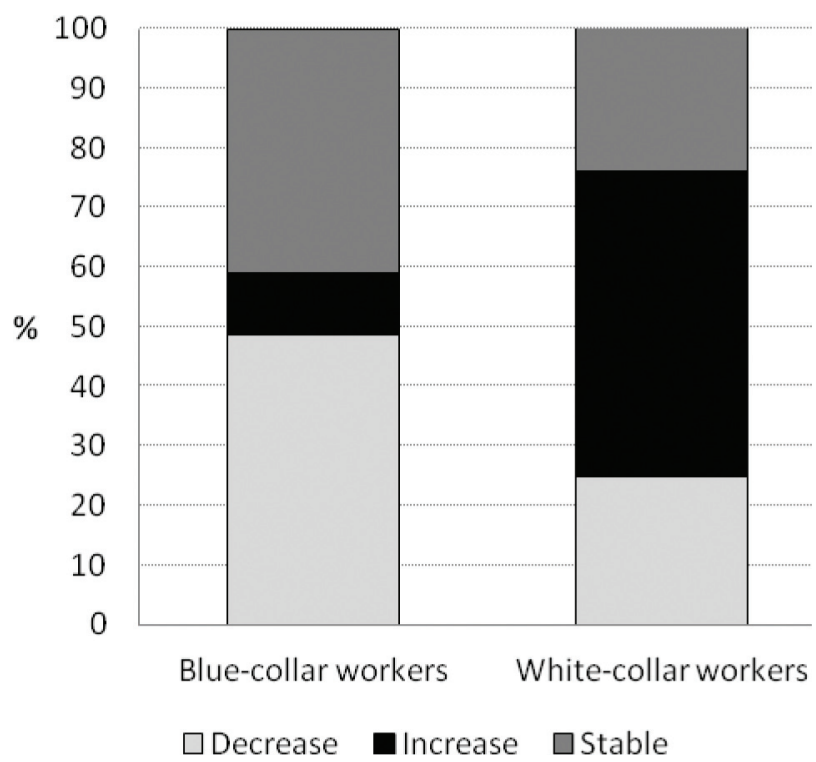


The explanatory factors for the changes in the earnings of the reemployed were analyzed by using the multinomial regression model. The changes in earnings were classified into three categories: increased, declined, and stable earnings. Those whose income had remained at the same level after reemployment were used as the reference category (Table 5). According to the results, the multinomial model fits the data well enough and the model could explain $44 \%$ of the changes in earnings (Nagelkerke 0.436). The explanatory factors were gender, age, migration outside the province, the reason for leaving the company, education, occupational status, and the length of the work contract at Perlos.

Compared with those whose earnings remained the same, the women's risk of receiving a lower salary in the new job was higher than that of the men. Gender was the only statistically significant predictor when decrease in earnings was estimated.

Table 5 Explanatory factors for changes in the earnings of the reemployed. The reference group represents those whose earnings remained stable after reemployment.

\begin{tabular}{|c|c|c|c|c|}
\hline \multirow[t]{2}{*}{ Predictors } & \multicolumn{2}{|c|}{ Decreased versus stable earnings } & \multicolumn{2}{|c|}{ Increased versus stable earnings } \\
\hline & OR & IOR & OR & IOR \\
\hline \multicolumn{5}{|l|}{ Gender } \\
\hline Women & $2.30 *$ & & 0.57 & 1.75 \\
\hline Men & । & & । & \\
\hline \multicolumn{5}{|l|}{ Age } \\
\hline under 35 years & 2.16 & & $6.03 *$ & \\
\hline $35-49$ years & 2.08 & & $5.40 *$ & \\
\hline over 50 years & । & & । & \\
\hline \multicolumn{5}{|l|}{ Migration } \\
\hline Out-migration from the province & 2.14 & & 5.43 & \\
\hline No migration & 1 & & । & \\
\hline \multicolumn{5}{|l|}{ Reason for leaving the company } \\
\hline Laid off & 8.85 & & 2.13 & \\
\hline Resigned voluntarily & 1.12 & & 5.13 & \\
\hline Temporarily employed & 1.66 & & 3.86 & \\
\hline Reemployed by a new employer & I & & । & \\
\hline \multicolumn{5}{|l|}{ Education } \\
\hline Elementary and occupational & 0.88 & 1.14 & 1.48 & \\
\hline Tertiary & । & & । & \\
\hline \multicolumn{5}{|l|}{ Occupational status } \\
\hline Blue-collar workers & 1.24 & & $0.07 * * * *$ & 14.29 \\
\hline White-collar workers & । & & 1 & \\
\hline \multicolumn{5}{|l|}{$\begin{array}{l}\text { Duration of the work contract } \\
\qquad-3 \text { years }\end{array}$} \\
\hline 4-9 years & 1.26 & & $4.43^{*}$ & \\
\hline \multirow[t]{2}{*}{10 years or more } & 1.36 & & 2.01 & \\
\hline & I & & I & \\
\hline
\end{tabular}

Multinomial regression analysis, risk ratio, and statistical significance; significance levels: ${ }^{*} p<0.05, * * p<0.0$ l, ${ }^{*} * * p<0.00$ l. 
Furthermore, those who were laid-off had a much more higher risk of earnings loss than thosewhowerereemployed by a newemployer (whocontinued production operations of Perlos) or who resigned voluntarily, when the reference group was those whose earnings remained stable (the result was not statistically significant, however). The increase in earnings was statistically significant from the perspective of occupational status, the duration of the work contract at the previous job, and the employee's age. When comparing with those whose earnings remained the same, the blue-collar workers' earnings were less likely to increase than the white-collar workers' earnings in the new job. Those under 35 years old were more likely to earn more at the new job than those over 50 years. Those who worked at their previous job for less than 4 years were much more likely to receive higher earnings at the new job than those who had been employed at their previous job for more than 10 years. Furthermore, those who had voluntarily resigned were more likely to earn more at the new job than that of those who had been employed by the new employers (this difference was, however, not statistically significant). As to the reason for leaving the company, increases in earnings had most likely been experienced by those who were young, had a short-term work contract, and were white-collar workers. Respectively, the losses in earnings had most likely been experienced by women and those who were laid-off, when the reference group was the workers with no changes in earnings levels.

Explanations for the changes in the earnings levels can be examined from three theoretical points of view. According to the human capital theory, those who are laid-off have a risk of losing human capital. Those with long work histories within a single firm have accumulated firm-specific skills that are rewarded with payments, but these skills are for the most part not transferable. Usually, white-collar workers and those with higher education have more general skills that are transferable to other jobs. Other employers are also willing to reward these skills. Another explanation is that the displaced workers increase the labor supply and competition at the local labor market, so the employers can lower the wages of the new recruits. Due to tough competition, the job seekers are forced to accept lower wages. Third, it can be assumed that the change from shift work to day-time work, or from full-time employment to part-time employment, reduces the earnings as well.

In the Perlos case, it is possible to explain the differences in the changes of earnings between the white-collar and blue-collar workers with the human capital theory. Through education and work experience, the white-collar workers have accumulated human capital that is useful and has exchange value in other companies and the other employers are willing to reward this with even better wages than at the previous job. On the basis of results, it seems that other employers had been especially interested in the young workers who had been employed at Perlos for only a short time and whose earnings development was at the initial stages. Other employers competed for this labor and were even willing to reward it with higher wages compared with the previous employer. The blue-collar workers were in the opposite situation. The human capital of blue-collar workers is often firm-specific and has only a low demand in other firms. The decrease in earnings among the blue-collar workers can be also explained by changes in the working hours, since shift work affected the wage composition at the factory. Shift work may not be as common in the other firms, and therefore the wage level may decrease at the new job. Especially for women, the changes in the earnings can be caused by the change of occupation or industry. 


\section{Job search and paths to reemployment}

We also analyzed the methods and success in searching for a job. The hypothesis was that the workers who had been employed for a long time in the same company would lack experience in job searching but that they might have social networks that ease their reemployment. There is strong evidence that informal contacts and networks play an important role in the matching process (Klingvall 1998). The selectivity of job displacement may also affect the methods and the intensity of the job search. Previous research has even suggested that some of the laid-off workers do not actively search for new jobs, which increases the probability of remaining unemployed (Rouvinen 2003). We analyzed the job search channels, such as using the services of the employment office or the labor rental agencies, applying for open vacancies, taking part in recruitment events, using informal job search methods, such as personal relationships, or direct calls to previous employers.

As a result of a plant closing, labor is freed up onto the market. Other firms can actively search for new labor by directly contacting workers under risk of job loss, employment agencies, or the employer who reduces labor. The other firms can also use the so-called passive methods of recruitment, e.g., wait for direct contacts or job applications from the job seekers (Klingvall 1998). In the Perlos case, this kind of explanation is relevant because the employment office, employees themselves, and other local actors organized several recruitment events in order to inform the employers of the qualifications of the freed-up labor.

According to the results of previous studies, job seekers find new jobs through direct contacts, either the new employer contacts the job seeker or the job seeker contacts the new employer. Reemployment possibilities increase if the person is a former employee of the firm, which recruits new labor. Informal job search channels are significant in terms of reemployment for both employed and unemployed job seekers, as most people obtain information on new jobs through informal channels and networks (Harkman and Johansson 1995; Klingvall 1998; Korpi 2001; Rieucau 2008).

Three groups were formed when the job search methods and reemployment paths of the individuals were studied: those who were laid-off (269), those who resigned voluntarily (54), and those with temporary work contracts (19). We expected that there would be differences in the job search methods and reemployment paths between these groups. In all groups, direct contact with employers and the sending of applications to open positions were the most common methods used. Those who had had temporary work contracts or had resigned voluntarily were more successful in finding employment with these methods than the others (Table 6).

Almost half $(48.1 \%)$ of those who resigned voluntarily had been reemployed by contacting the employer directly and one quarter $(25.9 \%)$ had been hired via a direct contact made by the employer. Also, $46.3 \%$ of the respondents indicated that they had been reemployed by sending an application to an open vacancy. The results clearly show that several methods are used simultaneously in the job search process. Those who had been laid-off had been more active in their job search and used more multiple methods than the other groups, despite the fact their job search was not more successful than that of the others. Of the laid-off workers, only less than one-third indicated that they had not directly contacted employers when looking for jobs. Over $70 \%$ had sent applications to open vacancies and almost half had sent applications to employers with- 


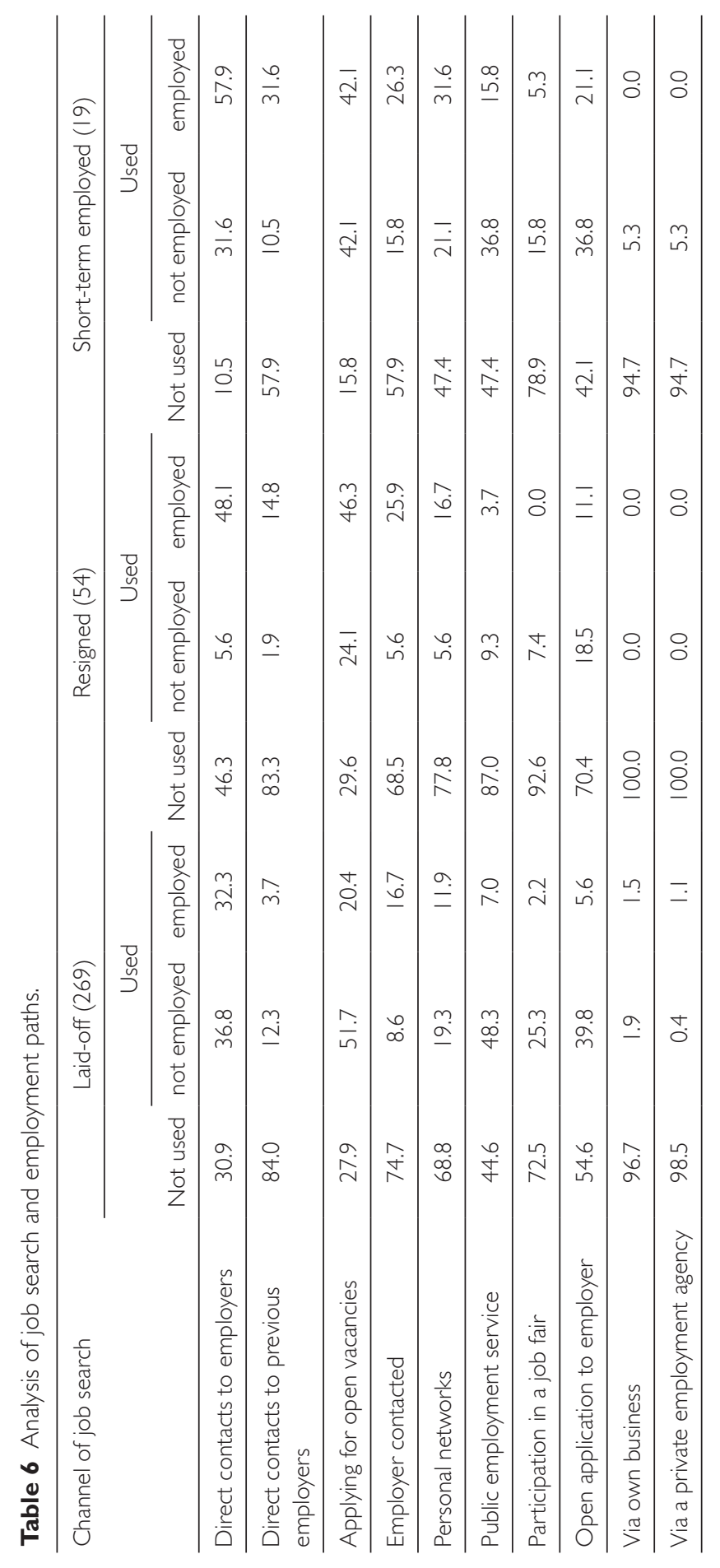


out knowledge of any open vacancy. The people who had had temporary work contracts had tried to find jobs through personal contacts or by directly contacting former employers more often than the other groups. Almost one-third had succeeded in getting a job by contacting former employers. Based on the results, it seems that the people who had had temporary work contracts had a better contact network than the other groups and the networks turned out to be useful when looking for reemployment. Those who were laid-off and remained unemployed had actively searched for new employment by using different channels but had been less successful in finding new jobs compared with the other groups.

\section{Conclusions}

The fast reemployment after the layoffs was a surprise that can be explained by the good demand and the hidden need for labor in the other firms in the region. The young age of the staff and the work experience acquired at Perlos were respected by the other employers, giving the laid-off people better reemployment opportunities compared with the other groups of job seekers.

The statistical analyses verify that the probability of reemployment was much higher for the white-collar workers than for the blue-collar workers. Being over 50 years of age increased the risk of unemployment when compared with those who were under 35 years old or with the 35- to 49-year-olds. Education, willingness to move, and family status did not show up as statistically significant explanatory factors for reemployment. Half of the white-collar workers indicated an increase in their earnings, whereas the same was true only for $10 \%$ of the blue-collar workers. For half of the blue-collar workers and for one quarter of the white-collar workers, the earnings decreased. The women's risk of receiving a lower wage upon reemployment was higher than that of the men. For the laid-off workers, the risk of receiving a lower wage was higher than that of those who resigned voluntarily. The intensity of the job search and the channels used do not seem to predict reemployment. When the demand for labor is good, the laid-off workers search for employment actively and do not wait for severance pay. The results of this study cannot, however, clearly indicate whether the job seekers accept just any work or would rather wait for employment that matches their aspirations.

Our research supports the results of previous studies that indicate reintegration into the labor market is a strongly selective process. The results verify the significance of occupational status in reemployment. White-collar workers had better chances of reemployment. The research also showed that gender and occupational status were important predictors for reemployment. The age of the job seekers became, as expected, an important factor when predicting the risk of unemployment.

In terms of the effects on earnings, we assumed that the job loss would have both shorter and longer term impacts on earnings and that the largest loss of earnings would be experienced by the most experienced workers. Our results indicate that in the short term, the reduction in earnings level was more common than an increase or the earnings remaining the same. A closer analysis shows that the earnings development was influenced not only by the occupational status but also by gender, age, the duration of the work contract in the company, and whether the person had been laid off or had resigned voluntarily. Those who resigned voluntarily generally found better labor 
market positions and earned more than the others. The white-collar male workers with short work histories had good chances to earn higher wages in their new jobs than at Perlos.

The support actions of the Perlos plant closure were exceptionally well resourced and the laid-off workers were assigned support from the EU as well. Furthermore, the support actions targeted at the unemployed were promptly organized. During the plant closure, the economy was growing and the former employees of Perlos were desirable labor. Later on, the weakening of the economy also had a negative impact on reemployment and 2.5 years after the plant closed, almost one-third of the laid-off workers were unemployed. In the short term, the reemployment of the laid-off workers seemed to succeed better than expected, but in the longer term, the job loss might have been a financial and social risk for many of the workers. In Finland, the active labor market measures play a very significant role in promoting reemployment and reducing unemployment. Nevertheless, the question remains how much stronger the social selectivity of reintegration would have been if there were no buffering mechanisms and support for reintegration.

\section{References}

Appelqvist, J. (2007) Wage and Earnings Losses of Displaced Workers in Finland. VATTKeskustelualoitteita 422. Helsinki: Valtion taloudellinen tutkimuskeskus.

Bittaraev, A. (2011) Social Risks of Transitions within the Labour Market - A Case Study of Plant Closure. Master's thesis. Social policy. School of Social Sciences and Humanities, University of Tampere.

Carrington, W. J. (1993) 'Wage Losses for Displaced Workers: Is it Really the Firm that Matters?' Journal of Human Resources, 28(3): 435-462.

DesJardins , S. L. (2001) 'A Comment on Interpreting Odds-Ratios When Logistic Regression Coefficients Are Negative'. AIR Professional File, 81. The Association for Institutional Research. Available at: <http://airweb3.org/airpubs/81.pdf> [Accessed February 2, 2011].

Eliason, M. (2004) 'Lost Jobs, Broken Marriages'. Working Papers of the Institute for Social and Economic Research, paper 2004-21. Colchester: University of Essex.

Erikson, S. (2002) The Persistence of Unemployment: Does Competition Between Employed and Unemployed Job Applicants Matter? Dissertation Series 4:2002, IFAU-Institute, Uppsala University.

Frederiksen, A. and Westergaard-Nielsen, N. (2007) 'Where did they go? Modelling Transitions out of Jobs'. Labour Economics, 14(5): 811-828.

Gallo, W. T., Bradley, E. H., Siegel, M. and Kasl, S. V. (2001) 'The Impact of Involuntary Job Loss on Subsequent Alcohol Consumption by Older Workers'. The Journal of Gerontology Series B: Psychological Science and Social Sciences, 56: 3-9. The Gerontological Society of America.

Gibbons R. and Katz, L. F. (1991) 'Layoffs and Lemons'. Journal of Labor Economics, 9(4): 351-380.

Goldin, R. (2007) ‘Odds Ratios'. Stats articles 2008. Available at: <http://stats.org/stories/2008/ odds_ratios_april4_2008.html>[Accessed February 2, 2011].

Harkman, A. and Johansson, L. (1995) Vad bestämmer sökaktiviteten? Arbetsmarknad \& Arbetsliv, 1(2): 99-112.

Houle, M. and Von Audenrode, M. (1995) 'Job Displacement, Wages, and Unemployment Duration in Canada'. Labour Economics 2 (1): 77-91. Elsevier Science 
Jokivuori, P. and Hietala, K. (2007) Määrällisiä tarinoita. Monimuuttujamenetelmien käyttö ja tulkinta. Helsinki: WSOY.

Jolkkonen, A. (1998) Paikan vaibto. Tutkimus irtisanomisuhan alaisten naisten työmarkkinastrategioista ja paikallisista työmarkkinoista. Joensuun yliopiston yhteiskuntatieteellisiä julkaisuja N:o 29. Joensuu: Joensuun yliopisto.

Jolkkonen A. and Koistinen, P. (2002) 'Short-Term Employment - A Stepping Stone or Obstacle to Permanent Employment?' In Koistinen, P. and Sengenberger, W. (eds) Labour Flexibility - A Factor of Economic and Social Performance of Finland in the 1990s, pp. 205-226. Tampere: Tampere University Press.

Jolkkonen, A. and Kurvinen, A. (2009) Joustavuus ja turvallisuus irtisanomistilanteissa Tapaustutkimus Perlos Oyj:n tuotannon lopettamisesta Joensuun seudulla. Työ- ja elinkeinoministeriön julkaisuja. Työ ja yrittäjyys 72/2009. Available at: <http://www.tem. fi/files/25503/TEM_72_2009.pdf> [Accessed August 6, 2011].

Kangasharju, A. and Pekkala, S. (2001) Regional economic repercussions of an economic crisis: a sectoral analysis. VATT Discussion Papers 248. Helsinki: Government Institute for Economic Research (VATT).

Kauhanen, M., Lilja, R. and Savaja, E. (2006) Työvoimapolitttisen koulutuksen vaikuttavuus kysynnän näkökulmasta. Työpoliittinen tutkimus 313. Helsinki: Työministeriö.

Kletzer, L. G. (1998) 'Job Displacement'. The Journal of Economic Perspectives, 12(1): 115-136. American Economic Association.

Klingvall, M. (1998) 'Företagens rekryteringsmetoder - hur arbetslösa får jobb'. Arbetsmarknad \& Arbetsliv, 4(4): 291-303.

Koistinen, P. (2002) 'Long-Term Unemployment in the Competition and Selection Process of Labour Market'. In Koistinen, P. and Sengenberger, W. (eds) Labour Flexibility - A Factor of Economic and Social Performance of Finland in the late 1990s, pp. 181-204. Tampere: Tampere University Press.

Koistinen, P. and Suikkanen, A. (eds) (1990) Edessä pysyvä tilapäisyys. Tapaustutkimus joukkoirtisanomisista ja niistä suoriutumisesta. Joensuun yliopisto. Karjalan tutkimuslaitoksen monisteita 2/1990. Joensuu: Joensuun yliopisto.

Korkeamäki, O. and Kyyrä, T. (2008) A Distributional Analysis of Displacement Costs in an Economic Depression and Recovery. VATT Discussion Papers 465, Government Institute for Economic Research (VATT). Available at: <http://www.vatt.fi/file/vatt_publication_pdf/k465.pdf> [Accessed September 26, 2011].

Korpi, T. (2001) 'Good Friends In Bad Times? Social Networks and Job Search Among the Unemployed in Sweden'. Acta Sociologica, 44(2): 157-150.

Kurvinen, A. (1999) Tilinteon aika. Tutkimus pankista työnsä menettävien naisten identiteetin undelleen arvioinneista. Joensuun yliopiston yhteiskuntatieteellisiä julkaisuja Nro 41. Joensuu: Joensuun yliopisto.

Kurvinen, A. (2001) 'Resources and Labour Market Orientation of the Unemployed'. In Koistinen, P. and Sengenberger W. (eds) Labour Flexibility - A Factor of Economic and Social Performance of Finland in the late 1990s, pp. 227-253. Tampere: Tampere University Press.

Linnakangas, R. (1997) Työpaikan menetys: tutkimus työsubteen jatkumisen ja loppumisen sosiaalisista ehdoista. Acta Universitatis Lapponiensis 15. Rovaniemi: Lapin yliopisto.

Lucas, R. E., Clark, A. E., Georgellis, Y. and Diener, E. (2004) 'Unemployment Alters the Set Point for Life Satisfaction'. Psychological Science, 15(1): 8-13. American Psychological Society.

Malo, M. A. and Muñoz-Bullón, F. (2007) 'Long-term Effects of Involuntary Job Separations on Labour Careers'. Journal of Socio-Economics, 37(2): 767-788.

Martikainen, P., Mäki, N. and Jäntti, M. (2007) 'The Effects of Unemployment on Mortality Following Workplace Downsizing and Workplace Closure: A Register-based Follow-up Study of Finnish Men and Women during Economic Boom and Recession'. American Journal of Epidemiology, 165(9): 1070-1075. 
Melin, H. and Mamia, T. (eds) (2010) Tapaus Voikkaa. Teollisuusybteisö murroksessa. Tampereen yliopiston Porin yksikön julkaisuja 4. Pori: Tampereen yliopisto.

Myrskylä, P. (2006) Muuttoliike ja työmarkkinat. Työpoliittinen tutkimus 321. Helsinki: Työministeriö.

Pekkala, S. and Kangasharju, A. (2002) Adjustment to regional labour market shocks. VATT Discussion Papers 274. Helsinki: Government Institute for Economic Research (VATT).

Rieucau, G. (2008) 'Job Advertisements and Personal Networks: Two Specific Channels in the Spanish Labour Market'. Transfer: European Review of Labour and Research, 14(3): 469-480.

Rouvinen, M. (2003) Elämää pankkityön jälkeen. Tapaustutkimus liiketoimintaorganisaation rakennemuutoksen seurauksena työtä vaille jäävien ibmisten sopeutumisesta uuteen elämäntilanteeseen. Acta Universitatis Tamperensis 968. Tampere: Tampereen yliopisto.

Song, Y. (2007) 'Recall Bias in the Displaced Workers Survey: Are Layoffs Really Lemons?' Labour Economics, 14(3): 335-345.

Stevens, A. H. (1997) 'Persistent Effects of Job Displacement: The Importance of Multiple Job Losses'. Journal of Labour Economics, 15(1): 165-188.

Sullivan, D. and Von Wachter, T. (2006) Mortality, Mass-Layoffs, and Career Outcomes: An Analysis using Administrative Data. Federal Reserve Bank of Chicago. Revised November 2007. Working Paper Series WP-06-21.

Verho, J. (2008) Scars of Recession: the Long-Term Costs of the Finnish Economic Crisis. IFAU Working Papers 9. Available at: <http://www.ifau.se/upload/pdf/se/2008/wp08-09. pdf $>$ [Accessed October 13, 2011].

Waters, L. (2007) 'Experiential Differences between Voluntary and Involuntary Job Redundancy on Depression, Job-search Activity, Affective Employee Outcomes and Re-employment Quality'. Journal of Occupational and Organizational Psychology, 80(2): 279-299.

\section{End notes}

${ }^{1}$ This article is based on a case study carried out during 2008-2009 at the University of Eastern Finland. The research examined the reemployment of the displaced workers, the factors predicting reemployment, the organization of support measures in the region, and the significance of active labor market measures and change security model. A case study research design and methods were used; the research data consisted of a questionnaire directed at the workers, interviews with informants, documentary data, statistics and register-based information gleaned from the career system of the labor administration. The publication "Flexibility and security in a lay-off situation - A case study of closing down the Perlos Ltd plants in the Joensuu region" (in Finnish) is available on the Internet at http://www.tem. fi/files/25503/TEM_72_2009.pdf. The case study was financed by the Finnish Work Environment Fund and the Ministry of Employment and Economy of Finland. This article is financed by the Academy of Finland (Project: Re(de)commodification of Social Risks in the Context of Plant Closings).

${ }^{2}$ Detailed information on the change security model of Finland can be found at http://www. mol.fi/mol/en/99_pdf/en/92_brochures/change_security_20050715.pdf 